\title{
Developing Professional Skills of the Convict through Entrepreneurship Education
}

\author{
Pauline Balabuch, Antonio Carlos de Francisco, Eliane Pinheiro, \\ Carla Cristine Sokulski, João Paulo Aires
}

Postgraduate Programs in Science and Technology Education and Production Engineering, Federal University of Technology_Paraná (UTFPR), Ponta Grossa, Brazil

Email:paulinepb007@gmail.com

How to cite this paper: Balabuch, P., de Francisco, A. C., Pinheiro, E., Sokulski, C. C., \& Aires, J. P. (2019). Developing Professional Skills of the Convict through Entrepreneurship Education. Creative Education, 10, 3329-3344.

https://doi.org/10.4236/ce.2019.1013256

Received: November 7, 2019

Accepted: December 8, 2019

Published: December 11, 2019

Copyright $\odot 2019$ by author(s) and Scientific Research Publishing Inc. This work is licensed under the Creative Commons Attribution International License (CC BY 4.0).

http://creativecommons.org/licenses/by/4.0/

\begin{abstract}
The aim of this study was to propose an innovative model for the development of the convict's professional skills through the teaching of Entrepreneurship. The importance of this research resides in the survey and presentation of data that show the possibility of developing the convict's professional skills, which may provide their reinsertion in the labor market. Therefore, it is an exploratory study with qualitative approach that comprises two stages: sampling and analytical, which support the development and application of the model named Professional Education Program with emphasis on the Entrepreneurial Spiral-PEP with EnSp. Thereafter, the data analysis and the development of professional skills are presented, and the results point positively to the promotion of teaching Entrepreneurship to the convict through the PEP with EnSp. Thus, it becomes evident the opportunities for learning and development of the convicts' professional skills through the teaching of Entrepreneurship, with an innovative model, in order to promote employability among individuals who need to be reinserted in the labor market.
\end{abstract}

\section{Keywords}

Professional Education, Teaching, Entrepreneurship Education, Innovation, Professional Skills, Convict

\section{Introduction}

The information exchange process is basically composed of education and work, providing individuals with conditions to insert themselves in the world, understand their social reality and know how to transform it into something better, by means of an effective posture and more proactive actions. Therefore, a clear and 
meaningful learning method for the adult can contribute to the development and improvement of their skills within the global web (Castells, 1999).

The convict's criminal record, despite them fulfilling their criminal sentence, does not contribute positively to their coexistence in society, due to their lack of education and also to social inequality, which leads to poverty and to the convict's consequent marginalization. The result observed is the contempt by members of society for the convict's negligible informational and economic contribution.

To this end, the Brazilian scenario provides measures through the programs Audience of Custody, Citizenship in Prisons, Start Again, Prison "Joint Effort", Prison Health, and Execution of Socio-educational Measures (CNJ, 2019). Moreover, specifically in the state of Paraná, the measures consist of assistance to prisoners in the areas of work, as well as religious, psychosocial, legal and material education (DEPEN, 2019).

The relevance of this study is in the presentation of a "Vocational Education Program with emphasis on the Entrepreneurial Spiral", hereinafter referred to as "PEP with EnSp". This program is an innovation in the teaching of entrepreneurship. It aims to qualify the convict based on administrative theories, so that they become an entrepreneur and are able to plan, open and maintain their own business, seeking not to depend on someone else's job.

Given that, one of the strategies of teaching entrepreneurship, linked to innovation, is the use of KSA-Knowledge Skill Attitude, for the development of individuals. For that, it is necessary that some characteristics be present in this learning, such as the subject's ability to identify, diagnose and explore new opportunities, perception of business feasibility, and understanding of market potential (Bosco et al., 2019).

The importance of this study lies in the presentation of an innovative model that develops the convict's professional skills through the teaching of entrepreneurship. These competencies are mapped and developed using the Entrepreneurship Spiral, which is the adjoining of the business plan and the business model canvas, providing an easy understanding on the logics of a business functioning and the consequent professional posture the person needs to have.

Therefore, it is presented the possibility of employability for people with criminal history, who see themselves at the mercy of a highly competitive and demanding market. The intention is to reduce the social impacts experienced by these individuals, providing them with an option to earn a legal income. Based on those assumptions, the objective of this paper is to propose an innovative model for the development of the convict's professional skills through the teaching of Entrepreneurship.

\section{Theoretical Contribution}

Faced with the new educational scenario, which base remains solid, as the objective remains in the scientific, ontological and epistemological preparation of the person as an active participant in the areas of social activity. To that end, the 
scientific and the empirical are increasingly mixed, providing an expanded understanding of human nature, its beliefs, habits, cultures and history (Palmer et al., 2018; Schuster et al., 2018; Hill, 2019).

One aspect that contributes to learner engagement is informed citizenship. It provides the understanding and evaluation between theory and practice of tangible technologies and science. That includes management science, which needs understanding and evaluation of everyday claims, for it seeks to promote new ways of teaching focused beyond the classroom (Baraças, 2017; Lin \& Chuang, 2018; Hill, 2019; Ribeiro et al., 2018).

Additionally, there is the set of Knowledge Skills Attitudes-KSA, which makes a professional be considered competent, since they use these elements in a functional way and in different contexts. In this case, the individual needs to present, mobilize and combine the right resources to achieve the desired result, as well as the set of rules, values and signals that bring out the sense of accomplishment of their work. The learning in all environments helps the subject to develop and expand their skills, achieving greater productivity and effectiveness, both personally and professionally (Martín-Rojas et al., 2017; Lin \& Chuang, 2018).

Regarding professional skills, the science of Management studies them in several areas, including the area of Human Resource Management, which is constantly evolving to accompany the development of people in the business market. Together with the personnel area, the study of entrepreneurship also makes constant use of skills, being linked to the innovation of: tasks-new activities in an existing process; structure-new processes in an existing system; and governance-new executions of processes and systems (Asemokha et al., 2019).

Thus, it is understood as innovation the act of performing a certain activity that already exists, in a new way, which may be a way of thinking, a process, a result and even a development. Since this development is a multifaceted process with diverse and collective impact, it is emphasized that it induces economic growth and also the growth of the individual as a human being, for it transforms this human being into a subject conscious of their needs, awakening in them the search for improvement. Improvements that are part of their social context, making them feel that they are capable of owning their own work: an entrepreneur. Thus, reflecting upon innovation in entrepreneurship education, it can be said that it is directly linked to the search for new business ideas (Kahn, 2018; Jimenéz \& Zheng, 2018; Asemokha et al., 2019).

Dornelas (2008), Ribeiro et al. (2018), Bosco et al. (2019) and Hill (2019) recall that the teaching of entrepreneurship emerged to supply professional qualification of former combatants of World War II. Only in the 1970s did it integrate university curricula. In Brazil, this emergence was still later, only in the 1990s.

According to Veiga et al. (2017), Lin and Chuang (2018) and Ribeiro (2018), it is believed that this recent teaching of entrepreneurship, together with innovation and the type of entrepreneur profile, promotes and raises interest in the study of this area in Brazil. The basis for entrepreneurship education is based on 
historical, socio-cultural and ethical factors of professionals in the area. Its goal is to train professionals who contribute to the economic development and prosperity of the country, as stated by Veiga et al. (2017) and Ribeiro et al. (2018).

Thus, there are two tools used to develop professional skills in the teaching of entrepreneurship through innovative businesses (Martin et al., 2018; Bosco et al., 2019). The first one is the business plan, which is a documentary tool that allows describing the main steps to implement a business, besides being a structured presentation before financial institutions, potential investors and partners (SEBRAE, 2019). The second is the business model, which is a visual tool consisting of the logical description of the idea, development and offer of product/service, determining how the individual can organize their business, both for themselves and their stakeholders, as customers, suppliers, shareholders and partners (Asemokha et al., 2019).

These two tools demonstrate that it is possible to learn in the most different ways, and the learner can seek information beyond school and university, in unlimited sources, but which need treatment to become knowledge. Hence, it is understood that this educational scenario needs new methodologies, thus emerging the active methodologies.

The precursor of references to active methodology is Montaigne (1533-1592), who preached that it was the preceptor's duty to pay attention to the child's intelligence, inflating it on new choices that contributed to the development of their discernment. After Montaigne, several authors defend in their pieces of work the idea of the active methodology, such as Comenius (1592-1670), John Locke (1632-1704), Rousseau (1701-1778), Johann Friedrich Herbart (1776-1841), William James (1842-1910), Adolphe Ferrière (1879-1960), Edouard Claparède (1873-1940), authors directly linked to biological and psychological Science (Araújo, 2015).

Specifically, the active methodology of Project-Based Learning-PBL, came into existence with John Dewey in 1897, which purpose is to make use of projects to encourage the resolution of real life problems and their contexts, by performing collective and cooperatives tasks, with the prerogative of presenting a final product. These projects are understood to be finite tasks, delimited by clear and concise objectives, with beginning, middle and end, which may be research, development, intervention or teaching-learning. To this end, the PBL is accomplished through six steps that contribute to the organization of the logic of the methodology's application to achieve the expected results, as follows: 1) introduction and planning; 2) initial research with information gathering; 3) creation, development and initial evaluation; 4) second phase of the research; 5) development of the final presentation; 6) product publication (Barbosa, 2013; Bender, 2014; Lin \& Chuang, 2018).

With regard to Peer Instruction, it was created and structured in 1992 for an initial physics course by Eric Manzur-a Dutch physicist and educator, professor at Harvard University. The purpose of the method is to improve learning 
and conceptual development, as well as broaden students' knowledge construction. Steps to be taken are: launching a question; individual resolution with a time limit of one minute; taking note of individual answer; interaction for two minutes with colleagues to compare answers; taking note of the final answer; feedback to the teacher; discussion and explanation of the correct answer (Manzur, 2015; Müller et al., 2017; Dini et al., 2019).

In Gamification, in turn the proposal is to make use of the elements, native techniques, strategies, methods and ways of thinking of games, in a real, external, and random environment. Its objective is to achieve greater involvement, freedom and participation of individuals in the proposed activity and the context in which it is inserted. The essential elements are: system; players; abstraction; challenge; rules; interactivity; feedback; quantifiable results; emotional reactions; story; score; ranking; badges (prizes/powers) (Pedro, 2016; Dini et al., 2019).

The individual, in the scenario of entrepreneurship education, is the same being that Nietzsche states to be formed by society and, as such, their rational and affective actions and capacities derive from it. It is emphasized that the individual and society are two correlated elements, bringing with them specificities of their reality. Compliance with the existing rules in this correlation works as a social identification of belonging or exclusion. It is up to the State, through the condemnation of criminal practices, to apply the process of exclusion from social coexistence to the individual identified and proven to be the author and responsible for damage and losses (Elias, 1994; Huss, 2011; Siemens, 2016; Martin et al., 2018; Bosco et al., 2019).

The set of incriminating norms is called Penal Code, but the process of exclusion from social coexistence is usually contained in the criminal enforcement legislation. In Brazil, in particular, the enforcement legislation was given a new format and came into force in 1985, from Law 7210/1984, better known as PEL-Penal Execution Law, consisting of nine chapters and 204 articles. Faced with Law 3274/1957, that legislation brought innovations regarding prison management, with the classification and definition of the types of prisons, and the description of the duties of the executing organs; the attention given to the convict in the matter of rights and duties; the determination that for every offense there is a sanction-equal penalty for all.

Notwithstanding the serving of sentence, it is believed that it is resocialization that will bring the imprisoned individual back to life. One of the ways to accomplish that is through education, which in prison is idealized to be a mechanism that allows the reeducation and resocialization of the convicts, to be used as a source of creativity, innovation and reflection, giving the individual an autonomy that can be put into practice when they get their freedom (Baratta, 1999; Julião, 2009; Arns \& Gomes, 2012).

At the federal level, there is the "Educating for Freedom Project", developed by the Ministry of Education together with the Ministry of Justice, which is supported by the United Nations Educational, Scientific and Cultural Organiza- 
tion-UNESCO. This project was born from two guidelines: the first was approved on May 19, 2010 by the National Education Council (Conselho Nacional de Educação-CNE) and was named "National Guidelines for the Provision of Education for Juveniles and Adults in Freedom Privacy Situation in Criminal Establishments"; the second was approved on March 11, 2009 by the National Council of Criminal and Penitentiary Policy (Conselho Nacional de Política Criminal e Penitenciária-CNPCP) and was named "National Guidelines for the Provision of Education in Criminal Establishments". With those guidelines and the "Educating for Freedom Project", it can be said that there has been a radical change in the history of convicts' education. Following the same precepts of the national project, in 2012, the "State Plan of Education in the Paraná State Prison System" was created (Moreira Neto, 2006; Julião, 2009, 2010; Arns \& Gomes, 2012).

That is why it is inferred that innovation in entrepreneurship education through PEP with EnSp can support life experience for the individual in prison. This statement is based on the fact that PEP with EnSp makes use of the Andragogic method in the innovation of entrepreneurship education, since the focus is contained on the goal the learner has. Moreover, it is that goal that determines whether direct or indirect teaching methods will be used. In this sense, Meaningful Learning complements this method, since it is known that the object to be learned has meaning for the learner, and that the learner shows willingness to relate the new object to the cognitive structure that they already have. Thus, learning becomes more attractive because the results are felt and internalized by the learner (Knowles et al., 1986; Crawford, 2008; Lin \& Chuang, 2018; Parappilly et al., 2019; Schuster et al., 2018).

\section{Research Methodology}

The theoretical contribution presented was built by means of research on the themes: "Professional Education", "Skills" and "Convict". Thus, it was possible to develop the educational product entitled PEP with EnSp.

It is provided a detailed description of the combination of the sampling and analytical stages, including four research steps for the present study, as well as the procedures used in bibliographic and field research, didactic product development, product intervention, and finally, data analysis using Ensslin et al. (2008)'s Multi-Criteria Decision-Aid-Constructivist (MCDA-C) and content analysis using the Spink (1999)'s Association Tree.

\subsection{Sampling Stage}

The definition of themes began with a survey and search for studies in the literature, guiding the initial sampling of articles through the definition of themes and scientific production (articles, theses and dissertations) in electronic databases: SciELO, LILACs, VHL and Google Scholar; with the descriptors, both in Portuguese and in English: educação profissional, competências, apenado; voca- 
tional education, skills, convict; it was delimited the period from 2000 to 2018 . For the first three databases no results were found; for the last one-Google Scholar-two results were found, of which only one dealt with the theme in Poland; the other dealt with Nordic policies for Australia.

The CAPES Journals portal, from 2001 to 2018 with the same descriptors, yielded one thousand and one hundred results, and three articles dealt with Vocational Education and convicts, focusing on short-term courses, without context and with certification purposes only; one thousand and ninety-five articles and dissertations on Professional Education and Skills, all focusing on technical and/or technological learning, with special attention focused on management courses, without even mentioning the convict; two, of skills and convicts, where one dealt with the degraded social environment of the convict; and the other about the skills that the fine arts can awaken in the convicts.

The field research took place at the Ponta Grossa State Penitentiary/Progression Unit (state of Paraná-Brazil)-PGSP/PU, which is a pilot unit where forty-three prisoners were transferred from the closed regime, after long technical work carried out jointly by the PGSP's own psychiatry, psychology, social assistance, legal and security sectors, which serve only the male public.

For the application of PEP with EnSp, a meeting was held at PGSP with the direction to adjust the schedule of activities and gather knowledge on the participating population. As it is a secure environment, nine prisoners from the closed PU regime, who work in some form of labor activity within the unit, were selected and had their participation allowed by the prison management as participants in the present study. The criteria used in the technical work are confidential and the researchers did not have access to these criteria.

The nine participants are characterized by an average age of $38.6,60 \%$ had not completed elementary school, $10 \%$ had completed elementary school and 30\% had completed high school. The average working time in seclusion is one year and four months. For data collection it was followed the steps of Management by Competencies, adapted from Marques (2013): diagnosis, capture, development, monitoring and evaluation of skills.

\subsection{Analytical Stage}

After identifying literature data and the bibliographic search, a field research was conducted, as already described in the sampling stage.

Next, the didactic product called PEP with EnSp was developed, based on the Andragogic method together with Meaningful Learning, having as parameter the active methodologies of PBL, Peer Instruction and Gamification, through the Sebrae Business Plan and the business model Canvas.

PEP with EnSp is an innovation in entrepreneurship education, as it brings together the aforementioned plan and business model, providing agility and greater understanding to the description of the product/service being created, since it calls for the use of previous experience and acquired knowledge. 
The convict's personal and professional development happens when they relate the knowledge acquired in labor therapy to everyday life, since to fill each phase of the spiral they will need to access the knowledge bank contained in their memory. It will also relate this knowledge to their past experiences. They will also make use of scientific, technological, socio-historical content and professional skills, and they will have to articulate between general and specific knowledge.

The PEP begins with the mapping of individual professional skills through the audit of skills, which if presenting "gaps", are forwarded to the targeted activities. Within the targeted activities is the RIASEC diagnosis, determining which business area the convict should describe in their EnSp, which is composed of five phases, as seen in Table 1.

Upon completion of EnSp, the performance assessment is conducted to prove the development of pre-established skills. Upon completion, the program can provide a second labor alternative to the convict when he or she returns to society, as he or she already has the plan for a validated new business.

The analysis of the data obtained from the application of PEP with EnSp occurred through the Multicriteria Decision Aid Methodology-Constructivist (MCDA-C), which comprises three phases in its learning measurement process: Phase 1-Decision context structuring: presenting data to be analyzed and transformed into information; Phase 2-Evaluation model: with alternatives and/or actions to be taken based on the information generated in Phase 1; Phase 3-Results: Presentation of the results obtained in Phase 2, before the formulation of recommendations (Ensslin et al., 2008).

To support the MCDA-C, the Kirkpatrick Model (Baraças, 2017) was used, which aims to verify the effectiveness and demand on the use of appropriate data collection instruments. Such model proposes four levels of assessment measure: reaction, learning, transference, and results. In this research, levels 1 and 2 were used to conduct the training evaluation and these were the basis for the decision of certificating or not the completed training. It needs to be reminded that this is a never-ending progressive process, because with each evolution felt by the individual, new objectives and goals must be set, continuing their training.

Finally, for the content analysis, among the visualization techniques presented Table 1. EnSp phases and their composition.

\begin{tabular}{ccc}
\hline Phase Number & EnSp Phase & Phase Composition \\
\hline 1 & Business & Mission, Vision, Values, and Industry \\
2 & Customers & Segment, relationship, and deliveries \\
3 & Structure & Tasks, Resources, Suppliers, and Competitors \\
4 & Financial & Revenues and Costs \\
5 & Feasibility & Profitability, Net Present Value, Payback Time, and Breakeven \\
\hline
\end{tabular}

Source: own authorship (2019). 
by Spink (1999), it was chosen the Association Tree, because it supports the rigor of constructionist research when it states that "understanding how a given argument is built in eager to produce meaning in a dialogical context (p. 114)". The main feature of this methodology is the use of specific parts of speech as an indication to understand the construction of the argumentation of the subjects involved in the research, allowing the understanding "both of each person's history and the intrinsic dialog of the process (p. 114-115)" of opinion expression.

\section{Results}

Given the theoretical background, it is presented the evidences that support the results of the present study, starting with the Spink Association Tree (1999), which was constantly used to add the qualitative factor to this research, in its content analysis, and to allow convicts to express themselves freely by contributing with voluntary and personal testimonials during the activities. Among those, it can be highlighted: "I already had a company out of here, but it didn't work out because I didn't know I needed this all to start a business. From what I'm seeing, I think you need a lot more. That's why I want to take the full course, to get out of guessing and to be sure. Only then will I have a business that works."

Thus, it is reported that the application of the product PEP with EnSp began with the response to the mapping of individual professional skills and the Fraiman (2018)'s test-“What business is right for me?", where there was predominance of the following profiles: realistic-managerial (74\%), social-affective (73.3\%), and concrete-conventional (87.8\%). By observing the type of business and its respective labor occupation for each profile, it is noticeable that the result is consistent with the life history and professional occupations previously practiced by the convicts.

As a final result of EnSp, three basic types of business were built, it is presented in Figure 1: gardening and landscaping, cafeteria and grocery store, service provision and construction. The vocation to entrepreneurship was noticeable, as described by SEBRAE (2019) in the profile of the Brazilian entrepreneur-predominance of class $C$ and an average age of 39 .

It was found that the convicts, even though they had had no previous contact with administrative planning tools - a fact diagnosed during skill mapping-, met the proposed model spontaneously and exceeded the expectations of the researchers, as well as fit the entrepreneurial profile and description of a competent professional. This situation is affirmed by Ribeiro et al. (2018) when explaining that it is through knowledge, skills and attitudes that the learning process occurs, and the subsequent practical externalization, making the behavioral change in entrepreneurship learners noticeable, since the structure of the individual KSA is evidenced in the activity performed.

Ribeiro et al. (2018) contribute to elucidate the understanding of the interest shown by the convicts to the theme "entrepreneurship". Those authors recognize 


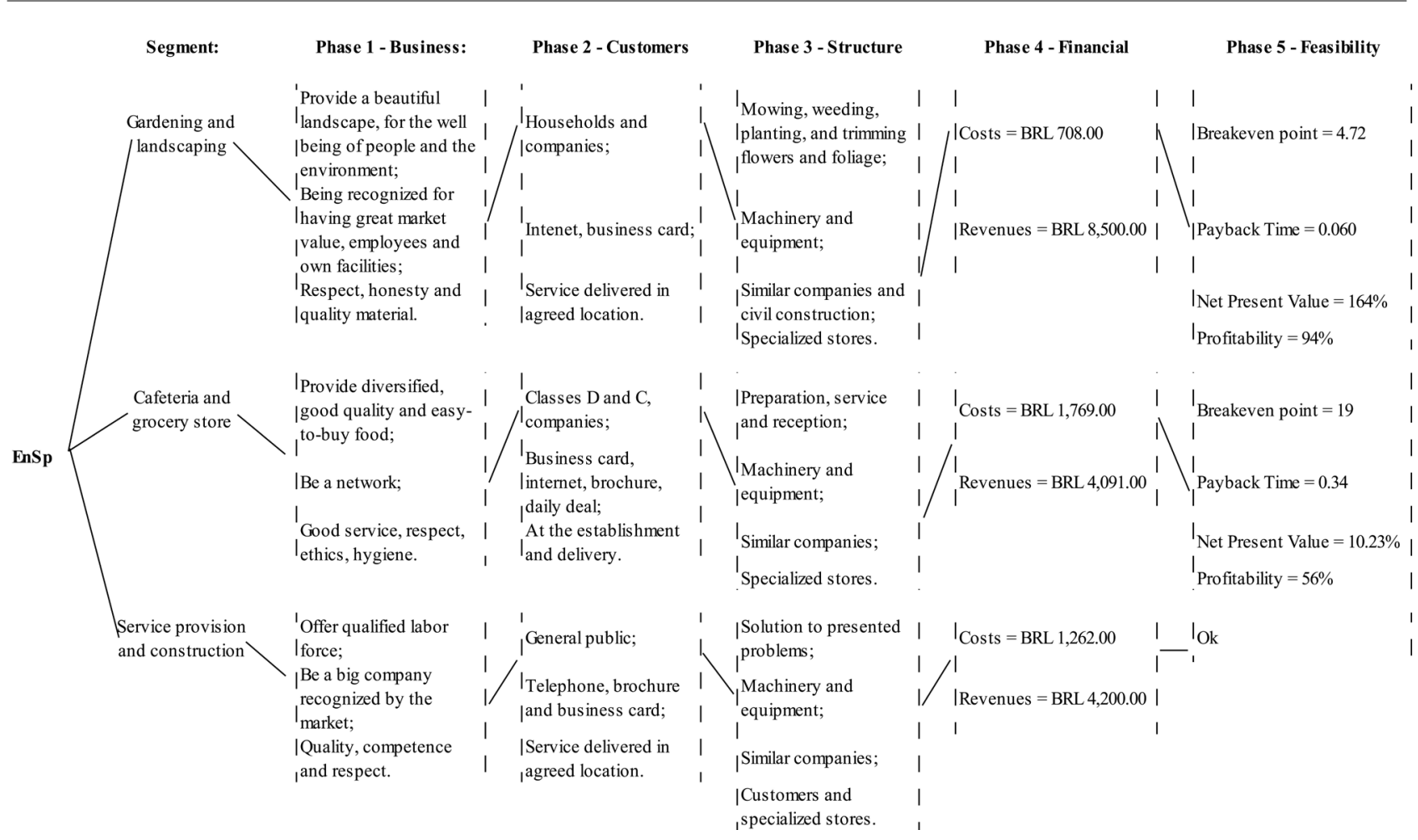

Source: own authorship (2019).

Figure 1. Association tree-EnSp completed and compiled.

that innovative entrepreneurial learning brings access to functional and systemic knowledge of the organizational process. This knowledge is very similar to the practical experience of life. Such learning is provided by the informal education of reflected and rethought collective knowledge. Moreover, it is learning by doing that enriches the professional practice of any individual, including convicts.

To measure the development of professional skills and their respective learning, Kirkpatrick's level 2 learning assessment was conducted, both at the beginning of the product application, with the mapping of skills, as on the last day of intervention, with the performance evaluation-follow up, as mentioned in the methodology, analytical stage, item 3.2, based on Baraças (2017). The analysis of results was based on the comparison of the answers obtained, where professional skills grew by $1.6 \%$ for entrepreneurial capacity; $0.5 \%$ for assertiveness; and $0.4 \%$ for cooperation. In Table 2, it is possible to see the three main professional skills and the twenty-four sub-skills that derive from them.

It is believed that the improvement of perceptions among the convicts was due to the content available for use during the application of the product, since details, concepts and explanations brought new knowledge that was anchored to the previous knowledge demonstrated in the mapping, which made the follow up evaluation to have a deeper understanding of the questions answered in the form. To reach this conclusion, two evaluations were conducted: one before starting the content, and another after adoption of the teaching strategy.

In this situation, this is the typical scenario of both the application of Andragogy 
Table 2. Professional skills.

\begin{tabular}{|c|c|c|c|}
\hline \multicolumn{2}{|c|}{ PROFESSIONAL SKILLS } & $\mathrm{K}$-Knowledge & A-Attitude \\
\hline \multirow{5}{*}{ 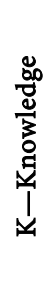 } & \multirow{5}{*}{$\begin{array}{c}\text { ENTREPRENEURIAL } \\
\text { CAPACITY }\end{array}$} & Planning & Initiative and Proactivity \\
\hline & & Analysis Capability & Decision making \\
\hline & & Strategic vision & Creativity \\
\hline & & Systemic vision & Organization \\
\hline & & Control Capability & Risk and responsibility \\
\hline \multirow{4}{*}{ i } & \multirow{4}{*}{ ASSERTIVENESS } & Sustainability and citizenship & Adaptation \\
\hline & & Marketing & Autonomy \\
\hline & & Communication & Flexibility \\
\hline & & Informatics/Technology & Self development \\
\hline \multirow{3}{*}{ 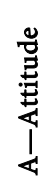 } & \multirow{3}{*}{ COOPERATION } & Entrepreneurship & Dynamism and Persistence \\
\hline & & Human resource management & Leadership and sociability \\
\hline & & Team work & $\begin{array}{c}\text { Interpersonal Relations and } \\
\text { Empathy }\end{array}$ \\
\hline
\end{tabular}

Source: own authorship (2019).

and Meaningful Learning. The respective evidences are the 1) option to use a direct method, since the set of concepts demanded their expansion, as directed by Crawford (2008), and 2) the use of potentially significant materials, which brought about an autonomous discovery based on their previous knowledge, which interacted cognitively with the new ones, providing a concrete change of reasoning (Ribeiro et al., 2018), generating the condition for Meaningful Learning. Specifically regarding the skills that were mapped and evaluated, these demonstrated a direct connection between the personal and professional dimensions (Nóvoa, 1991) of the participants, leading them to reflect on their social qualification, evaluating and classifying their new knowledge as pertinent to the future posture of entrepreneurs (Manfredi, 1998). During the elaboration of the mission, vision and values of their companies, that fact is also demonstrated making noticeable their level of awareness about their responsibility and recognition, which will be expressed on their professional performance (Brandão, 2009) when conducting their own business (SEBRAE, 2019), upon their release and consequent opening of the business.

In Table 3, it is possible to visualize the professional skills and their respective sub-skills that were developed in each phase of EnSp.

It is noteworthy that the analysis of the data obtained in the application of PEP with EnSp, concomitantly with the product implementation, took place via the Multicriteria Decision Aid Methodology-Constructivist (MCDA-C), as it was used a programmed instructional process, composed of five small phases, which allowed an active return from the participating convicts; and, on the part of the researchers, an immediate verification and a test of the complete program 
Table 3. Skills developed in EnSp.

\begin{tabular}{|c|c|c|c|c|c|}
\hline & & & & $s-$ & Skills \\
\hline & OFESSIONAL SKILLS & $\begin{array}{l}\text { K-Knowledge } \\
\text { Theoretical background }\end{array}$ & $\begin{array}{l}\text { A-Attitude } \\
\text { EnSp Practice }\end{array}$ & Phase & EnSp \\
\hline & & Planning & $\begin{array}{c}\text { Initiative and } \\
\text { Proactivity }\end{array}$ & 5 & Feasibility \\
\hline$\stackrel{\square}{\square}$ & & Analysis Capability & Decision making & 4 & Financial \\
\hline (3) & $\begin{array}{c}\text { ENTREPRENEURIAL } \\
\text { CAPACITY }\end{array}$ & Strategic vision & Creativity & 2 & Customers \\
\hline$\frac{1}{2}$ & & Systemic vision & Organization & 3 & Structure \\
\hline & & Control Capability & $\begin{array}{c}\text { Risk and } \\
\text { responsibility }\end{array}$ & 5 & Feasibility \\
\hline & & $\begin{array}{l}\text { Sustainability and } \\
\text { citizenship }\end{array}$ & Adaptation & 1 & Business \\
\hline 青 & ASSERTIVENESS & Marketing & Autonomy & 2 & Customers \\
\hline is & & Communication & Flexibility & 2 & Customers \\
\hline & & Informatics/Technology & Self development & 5 & Feasibility \\
\hline & & Entrepreneurship & $\begin{array}{l}\text { Dynamism and } \\
\text { Persistence }\end{array}$ & 1 & Business \\
\hline 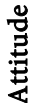 & COOPERATION & $\begin{array}{l}\text { Human resource } \\
\text { management }\end{array}$ & $\begin{array}{l}\text { Leadership and } \\
\text { sociability }\end{array}$ & 3 & Structure \\
\hline$\frac{1}{4}$ & & & Interpersonal & & \\
\hline & & Team work & $\begin{array}{l}\text { Relations and } \\
\text { Empathy }\end{array}$ & 2 & Customers \\
\hline
\end{tabular}

Source: own authorship (2019).

(Phase 1-structuring the decision context).

Within the same logic, it is noteworthy that it was presented to the convicts the whole EnSp, by means of an instructional process, making it clear that each new phase would only be applied upon completion with full use of the previous one. In addition, despite that requirement, who would set the pace of studies would be each convict, given their difficulties and understanding. Thus, it was possible to comply with the schedule, application, evaluation and reschedule of activities, being that this last activity would be needed in case there were individual difficulties that required the interruption of class progress, which did not occur in the participating class (Phase 2-Evaluation model).

To provide meaning during the execution of the EnSp, it was proposed that each convict elaborate their activity making use of previous knowledge acquired both in the context of free life and the current environment where they are inserted-the interaction between them and their classmates (Phase 3-Results).

Given the information collected, it was possible to perform the treatment through the Ensslin et al. (2008)'s MCDA-C's data analysis, and content analysis based on Spink (1999)'s Association Tree, relating the obtained result with the theoretical background, as presented in this section. 


\section{Conclusion}

The present study aimed to propose an innovative model for the development of the convict's professional skills through the teaching of Entrepreneurship. Thus, it can be stated that the research objective was achieved, since the PEP with EnSp was proposed as an innovative model, which contributed to the development of the convict's professional skills through the teaching of Entrepreneurship, either by the product developed or by research locus, both of which are unprecedented. It also contributed to the convict's resocialization, through the concept of entrepreneurial attitudes, bringing a second option for reintegration of the convict in the labor market.

During the activities, the convicts expressed freely, contributing with voluntary and personal testimonials. The mapping and auditing of individual professional skills and the Fraiman (2018)'s test allowed verifying that the result is in line with the life history and previous professional occupation of the convicts. With such information, it was easy to fill the Entrepreneurship Spiral, and therefore, they obtained a plan for their future businesses.

The convicts' interest in the theme "entrepreneurship" was evident, since the innovative entrepreneurial learning allowed access to functional and systematic knowledge of the organizational process. Those pieces of knowledge are very similar to practical experiences from life, enabled by the informal education of collective knowledge that enriches the professional practice (of any individual) as a whole.

The context of the present study is differentiated because the learners were convicts whose roles and responsibilities gave rise to specific expectations about what it means to learn, especially to have a second option in life. Those expectations, which have cultural, conceptual and social dimensions, influenced their engagement in the participation in the PEP with EnSp.

The results, therefore, were limited to a specific participating population, and interpretations are linked to that context. It would be important to extend the study to other populations of apprentices, including semi-open convicts, female convicts, and other prison units in the state and in the country.

Thus, the relentless pursuit for skilled professionals is a maxim that will endure in human resource management as long as human capital is needed to produce goods and services. Thus, it is concluded that the didactic product PEP with EnSp, is an effective methodology in the prison educational scenario, with emphasis on people, since it emphasizes the innovation in teaching entrepreneurship for the realization of the professional skills of the convict.

\section{Conflicts of Interest}

The authors declare no conflicts of interest regarding the publication of this paper.

\section{References}

Araújo, J. C. S. (2015). Fundamentos da metodologia de ensino ativa (1890-1931). In 
REUNIÃO NACIONAL DA ANPED, 37a, 2015, Florianópolis. Anais... Florianópolis: UFSC.

Arns, F., \& Gomes, M. T. U. (2012). Plano estadual de Educação no sistema prisional do Paraná. Curitiba.

Asemokha, A. et al. (2019). Business Model Innovation and Entrepreneurial Orientation Relationships in SMEs: Implications for International Performance. Journal of International Entrepreneurship, 17, 425-453. https://doi.org/10.1007/s10843-019-00254-3

Baraças, A. R. C. (2017). Avaliação da formação segundo o modelo de Kirkpatrick. Masters Degree Dissertation, Liboa: Lisboa University.

Baratta, A. (1999). Criminologia crítica e crítica do direito penal: Introdução à sociologia do direito penal. Tradução Juarez Cirino dos Santos (2nd ed.). Rio de Janeiro: Freitas Bastos ICC.

Barbosa, E. F. et al. (2013). Metodologias ativas de aprendizagem na educação profissional e tecnológica. Boletim Técnico SENAC, 39, 48-67, maio/ago.

Bender, W. N. (2014). Aprendizagem baseada em projetos: Educação diferenciada para o século XXI. Tradução de Fernando de Siqueira Rodrigues. Porto Alegre: Penso. https://doi.org/10.13058/raep.2016.v17n3.440

Bosco, B. D. et al. (2019). Fostering Entrepreneurship: An Innovative Business Model to Link Innovation and New Venture Creation. Review of Managerial Science, 13, 561-574. https://doi.org/10.1007/s11846-018-0318-8

Brandão, H. P. (2009). Aprendizagem, contexto, competência e desempenho: Um estudo multinível. PhD Thesis, Brasília: Brasília University.

Castells, M. (1999). A sociedade em rede(Vol. 1). São Paulo: Paz e Terra.

CNJ Conselho Nacional de Justiça (2019). Sistema Carcerário, Execução Penal e Medidas Socioeducativas. http://www.cnj.jus.br/sistema-carcerario-e-execucao-penal

Crawford, S. R. (2008). Andragogy. Journal of International Education in Business, 1-4.

DEPEN-Departamento Penitenciário (2019). Dados do Departamento de Execução Penal do Estado do Paraná. http://www.depen.pr.gov.br

Dini, V. et al. (2019). Dynamics of Scientific Engagement in a Blended Online Learning Environment. Research in Science Education, 1-29. https://doi.org/10.1007/s11165-018-9802-z

Dornelas, J. C. A. (2008). Empreendedorismo: Transformando ideias em negócios. Rio de Janeiro: Elsevier.

Elias, N. (1994). A sociedade dos indivíduos. Rio de Janeiro: Jorge Zahar Ed.

Ensslin, S. et al. (2008). Uma metodologia multicritério (MCDA-C) para apoiar o gerenciamento do capital intelectual organizacional. RAM, 9, 136-162. https://doi.org/10.1590/S1678-69712008000700007

Fraiman, L. (2018). Teste de J. Holland. http://revistapegn.globo.com/Revista/Common/0,ERT81412-17152,00.html

Hill, C. T. (2019). STEM Is Not Enough: Education for Success in the Post-Scientific Society. Journal of Science Education and Technology, 28, 69-73. https://doi.org/10.1007/s10956-018-9745-1

Huss, M. T. (2011). Psicologia forense: Pesquisa, prática clínica e aplicações. Porto Alegre: Artmed.

Jimenéz, A., \& Zheng (2018). Tech Hubs, Innovation and Development. Information Technology for Development, 24, 95-118. https://doi.org/10.1080/02681102.2017.1335282 
Julião, E. F. (2009). A ressocialização por meio do estudo e do trabalho no sistema penitenciário brasileiro. $\mathrm{PhD}$ Thesys, Rio de Janeiro: Rio de Janeiro State University.

Julião, E. F. (2010). O impacto da Educação e do trabalho como programas de reinserção social na política de execução penal do Rio de Janeiro. Revista Brasileira de Educação, 15, 45. https://doi.org/10.1590/S1413-24782010000300010

Kahn, K. B. (2018). Understanding Innovation. Business Horizons, 61, 453-460. https://doi.org/10.1016/j.bushor.2018.01.011

Knowles, M. S. et al. (1986). Andragogy in Action: Applying Modern Principles of Adult Learning. Canadian Journal of Communication-Journal of International Business Studies, 12, 77-80.

Lin, C., \& Chuang, S. S. (2018). Role of Empathy between Functional Competence Diversity and Competence Acquisition: A Case Study of Interdisciplinary Teams. Quality \& Quantity, 52, 2535-2556. https://doi.org/10.1007/s11135-018-0794-6

Manfredi, S. M. (1998). Trabalho, qualificação e competência profissional-Das dimensões conceituais e políticas. Educação e Sociedade, 19, 13-49. https://doi.org/10.1590/S0101-73301998000300002

Manzur, E. (2015). Peer Instruction: A revolução da aprendizagem ativa. Tradução de Anatólio Laschuk. Porto Alegre: Penso.

Marques, F. (2013). Guia de Mapeamento e Avaliação de Competências para a Administração Pública do Poder Executivo. República Federativa do Brasil e União Europeia, projeto "Diálogos Setoriais".

Martin, A. M. et al. (2018). Effectual Reasoning and Innovation among Entrepreneurial Science Teacher Leaders: A Correlational Study. Research in Science Education, 48, 1297-1319. https://doi.org/10.1007/s11165-016-9603-1

Martín-Rojas, R. et al. (2017). Encouraging Organizational Performance through the Influence of Technological Distinctive Competencies on Components of Corporate Entrepreneurship. International Entrepreneurship and Management Journal, 13, 397-426. https://doi.org/10.1007/s11365-016-0406-7

Moreira Neto, A. L. C. (2006). Múltiplas visôes sobre as atividades de trabalho remunerado, desenvolvidas na penitenciária estadual de Maringá. Dissertation, Maringá: Universidade Estadual de Maringá. https://doi.org/10.13037/gr.vol27n79.1070

Müller, M. G. et al. (2017). Uma revisão da literatura acerca da implementação da metodologia interativa de ensino Peer Instruction (1991 a 2015). Revista Brasileira de Ensino de Física, 39, e.3403. https://doi.org/10.1590/1806-9126-rbef-2017-0012

Nóvoa, A. (1991). Para o estudo sócio-histórico da gênese e desenvolvimento da profissão docente. Teoria \& Educação, 4, 109-139.

Palmer, S. et al. (2018). Occupational Outcomes for Bachelor of Science Graduates in Australia and Implications for Undergraduate Science Curricula. Research in Science Education, 48, 989-1006. https://doi.org/10.1007/s11165-016-9595-x

Parappilly, M. et al. (2019). Feasibility and Effectiveness of Different Models of Team-Based Learning Approaches in STEMM-Based Disciplines. Research in Science Education, 1-15. https://doi.org/10.1007/s11165-019-09888-8

Pedro, L. Z. (2016). Uso da gamificação em ambientes virtuais de aprendizagem para reduzir o problema da externalização de comportamentos indesejáveis. Dissertation, São Carlos: Universidade de São Paulo. https://doi.org/10.11606/d.55.2016.tde-08122016-170652

Ribeiro, A. T. V. B. et al. (2018). Building Builders: Entrepreneurship Education from an Ecosystem Perspective at MIT. Triple Helix, 5, 1-20. 
https://doi.org/10.1186/s40604-018-0051-y

Schuster, D. et al. (2018). Learning of Core Disciplinary Ideas: Efficacy Comparison of Two Contrasting Modes of Science Instruction. Research in Science Education, 48, 389-435. https://doi.org/10.1007/s11165-016-9573-3

SEBRAE Serviço Brasileiro de Apoio às Micro e Pequenas Empresas (2019). Perfil do empreendedor brasileiro. Software Plano de Negócio 3.0. http://www.sebrae.com.br/sites/PortalSebrae

Siemens, H. (2016). Nietzsche e a sociofisiologia do eu. Caderno Nietzsche, 37, 185-218. https://doi.org/10.1590/2316-82422016v37n1hs

Spink, M. J. (1999). Práticas discursivas e produção de sentidos no cotidiano: Aproximações teóricas e metodológicas. São Paulo: Cortez.

Veiga, H. M. S. et al. (2017). The Psychology of Entrepreneurship. In E. Neiva, C. Torres, \& H. Mendonça (Eds.), Organizational Psychology and Evidence-Based Management (pp. 135-155). Cham: Springer. https://doi.org/10.1007/978-3-319-64304-5_8 